\title{
SEGREGATIVE INTENT AND THE SINGLE GOVERNIMENTAL ENTITY IN SCHOOL DESEGREGATION
}

In Bradley v. Milliken [Detroit], ${ }^{1}$ the Court of Appeals for the Sixth Circuit held that it is within the power of a federal district court to order implementation of a metropolitan area desegregation plan, where the crossing of school district lines is necessary to eliminate de jure segregation. Although the "white flight" to the suburbs has had a profound impact on school desegregation and public education, ${ }^{2} \mathrm{De}$ troit recognizes for the first time that the power exists to break down the Jegal barriers that heretofore have perpetuated white suburban "sanctuaries."

The alacrity with which the Sixth Circuit ordered a city-suburban pupil exchange may be surpassed only by the eagerness with which the Fourth Circuit disposed of a similar "consolidation" proposal. ${ }^{3}$ In Bradley v. School Board [Richmond], ${ }^{4}$ the Fourth Circuit reversed the district court's order to impleinent a inetropolitan desegregation plan, on the grounds that the complete elimination of state-imposed seggregation within the individual districts obviated further judicial intervention. ${ }^{5}$ The decision in the Richmond case was affirmed by an equally divided Supreme Court, ${ }^{8}$ and therefore legal questions pertaining to urban school desegregation persist. ${ }^{7}$

1. 484 F.2d 215 (6th Cir.), cert. granted, 42 U.S.L.W. 3300 (U.S. Nov. 20, 1973) (Nos. 73-434 to -436).

2. It has been predicted that

ten or twenty years from now, if present trends continue unchecked, all but a small minority of the Negro and white children who live in the major cities and suburbs of urban America will attend separate schools. The contemporary European caricature of the United States as a country in which selfsatisfied white people live prosperously in suburban sanctuaries which surround our large cities or in high-rent urban residential areas and black citizens live in decaying central city slums will be caricature no longer. A. SCHECHTER, CONSTITUTIONAL IsSUES 231 (1972).

Cf. A. BICkel, The Supreme CoURT AND THE IDEA OF PROgRess 132 (1970).

3. Other cases in which a metropolitan-wide solution has been or is being considered imclude United States v. Board of School Comm'rs [Indianapolis], 474 F.2d 81 (7th Cir. 1973) and Calhoun v. Cook [Atlanta], 469 F.2d 1067 (5th Cir. 1972).

4. 462 F.2d 1058 (4th Cir. 1972), aff'd by an equally divided Court, 93 S. Ct. 1952 (1973).

5. Id. at 1069.

6. Mr. Justice Powell took no part in the decision.

7. See Note, Consolidation for Desegregation: The Unresolved Issue of the Inevitable Sequel, 82 YALE L.J. 1681 (1973). The cited authority takes the position that the holdings of Bradley v. Milliken and Bradley v. School Bd. are "directly con- 
The similarity of the underlying racial probleins in Detroit and Richmond cannot be ignored. Thus, while Detroit purports to distinguish itself froin Richmond, ${ }^{8}$ the results reached in the two cases appear contradictory. ${ }^{9}$ The Sixth Circuit held that the greater Detroit area must be viewed as one large "dual" system amenable to one metropolitan desegregation plan while the Fourth Circuit insisted that the three school districts comprising the greater Richmond area cannot be consolidated for purposes of school desegregation. ${ }^{10}$ This Note will atteinpt to reconcile the two seemingly contradictory approaches by suggesting that both involve an inquiry as to the presence of an unlawful metropolitan "intent to segregate," an intent which may objectively be imputed ${ }^{11}$ from the presence of segregated conditions only if the area's school policies are significantly controlled by one decision-making body. As a necessary preliminary to the detailed consideration of Detroit and Richmond, this Note will briefly review the basic de jure-de facto desegregation doctrine.

\section{Finding a Metropolitan Violation}

\section{The Attack on State-Imposed Segregation}

Application of the equal protection clause of the fourteenth amendment to school segregation cases has been a major judicial activity $^{12}$ since Chief Justice Warren concluded in Brown v. Board of Education [Brown I] that "[s]eparate educational facilities are inherently unequal."13 The early desegregation cases that followed Brown

tradictory." Id. at 1684 . This Note will argue that the two cases are reconcilable even though they reach a different result.

8. 484 F.2d at $250-51$.

9. See Note, supra note 7, at 1684 .

It is recognized, of course, that the "[l]aw provides us with many examples where a party may suffer identical harm under two different circumstances and have a legal right to redress under one and not the other." Kaplan, Segregation Litigation and the Schools-Part II: The General Northern Problem, 58 Nw. U.L. REv. 157, 176 (1963).

10. The difference between a "unitary" system and a "dual" system is not susceptible of precise definition, but "dual" generally refers to a public system which operates separate racially identifiable schools. See Alexander v. Holmes County Bd. of Educ., 396 U.S. 19 (1969); Green v. County School Bd., 391 U.S. 430, 435 (1967); The Supreme Court 1971, Term, 86 HaRv. L. Rev. 1, 65 (1972).

11. If intent may not be imputed, Keyes v. School Dist. No. 1 [Denver], $93 \mathrm{~S} . \mathrm{Ct}$. 2686 (1973), arguably mandates the introduction of other subjective factors to prove a de jure intent to segregate.

12. Cf. Swann v. Charlotte-Mecklenburg Bd. of Educ., 402 U.S. 1, 6 (1971).

13. 347 U.S. 483, 495 (1954). The Court noted that interpretation and application of the doctrine is a dynainic process:

In approaching this problem, we cannot turn the clock back to 1868 when 
$I$ struck down "officially imposed racial segregation in the schools"14 on "the unassailable de jure ground of the discriminatory constitutional and statutory provisions." 15 Thus, since judicial activism concentrated on those states which maintained two sets of schools within a single system in order "to carry out a governmental policy to separate pupils in schools solely on the basis of race,"16 constitutional standards governed only school segregation resulting from state segregation laws and not the de facto segregation resulting from a neighborhood school policy in a residentially segregated community. ${ }^{17}$ After the initial constitutional assault on "overt statutory segregation," the judicial focus turned to local coinpliance with the mandate of Brown $I^{18}$ The inquiry as to whether a particular situation anounted to actionable de jure segregation or constitutionally permissible de facto segregation no longer was a straightforward mechanical process, for the issue of local compliance did not confront the courts with highly visible discriminatory state statutes. Nevertheless, by continually expanding the paraineters of state action as a source of de jure segregation, ${ }^{19}$ the Supreme

the Amendment was adopted, or even to 1896 when Plessy v. Ferguson was written. We must consider public education in the light of its full development and its present place in American life throughout the Nation. Id. at 492-93.

14. Keyes v. School Dist. No. 1 [Denver], 93 S. Ct. 2686, 2703 (1973) (Powell, J., concurring in part and dissenting in part).

15. Id. at $2708 \mathrm{n} .15$ (Powell, J., concurring in part and dissenting in part).

16. Swann v. Charlotte-Mecklenburg Bd. of Educ., 402 U.S. 1, 6 (1971). See also Keyes v. School Dist. No. 1 [Denver], 93 S. Ct. 2686, 2703 (1973) (Powell, J., concurring in part and dissenting in part).

17. See Spencer v. Kugler, 326 F. Supp. 1235 (D.N.J. 1971), aff'd mem., 404 U.S. 1027 (1972); Deal v. Cincinnati Bd. of Educ., 419 F.2d 1387 (6th Cir. 1969), cert. denied, 402 U.S. 962 (1971); Bell v. School City of Gary, 324 F.2d 209 (7th Cir. 1963), cert. denied, 377 U.S. 924 (1964). See generally Goodman, De Facto School Segregation: A Constitutional and Empirical Analysis, 60 CALIF. L. REv, 275 (1972); Wright, Public School Desegregation: Legal Remedies for De Facto Segregation, 40 N.Y.U.L. REv. 285 (1965); Annot., 11 A.L.R.3d 780 (1967).

18. See, e.g., Wright v. Council of the City of Emporia, 407 U.S. 451 (1972); Swann v. Charlotte-Mecklenburg Bd. of Educ., 402 U.S. 1 (1971); Green v. County School Bd., 391 U.S. 430 (1968); Taylor v. Board of Educ., 294 F.2d 36 (2d Cir.), cert. denied, 368 U.S. 940 (1961); Note, supra note 7, at 1687.

19. "With the growth of the concept of state action, 'de facto' may give way to 'de jure' in all situations." Goldman, Benign Racial Classifications: $A$ Constitutional Dilemma, 35 U. CIN. L. Rev. 349, 349-50 (1966).

In his concurring opinion in Keyes v. School Dist. No. 1 [Denver], Mr. Justice Douglas argues for the abandonment of the de jure-de facto distinction on the grounds that "each is the product of state actions or policies." 93 S. Ct. at 2701. Because in his view a school board is an agency of the state, its actions-district gerrymandering, school site selection, pupil allocation, and budget preparation-therefore constitute state action for fourteenth amendment purposes. Id. at 2700.

The approach of broadening the concept of state action as a means of reaching de facto situations has been criticized because of the proof problems involved in estab- 
Court has, in effect, reserved the question of whether constitutional standards also govern traditional de facto segregation. ${ }^{20}$

\section{The Renewed De Jure-De Facto Dichotomy}

While the application of constitutional standards to de facto segregation may become increasingly significant as the effects of prior de jure segregation become attenuated with time, ${ }^{21}$ the most recent pronouncement of the Supreme Court in the area of school desegregation has renewed the vitality of the de jure-de facto distinction. In so doing, the Court in Keyes v. School District No. 1 [Denver ${ }^{22}$ held that the essential element of actionable de jure segregation was a finding of some official "intent to segregate": "We emphasize that the differentiating factor between de jure segregation and so-called de facto segregation to which we referred in Swann is purpose or intent to segregate." 23

Denver involved a class action on behalf of Denver school children against the city school board, alleging various segregative practices and conditions within the school district and seeking a decree directing desegregation of the entire district. The Court, speaking through Mr. Justice Brennan, held that a determination of segregation brought about by intentional action of the board in a "meaningful" segment of the system created a prima facie case of de jure segregation, ${ }^{24}$ which shifted to those authorities the burden of proving that

lishing the causal connection between the state action and its segregatory impact and in establishing the requisite element of intent. Note, De Facto School Segregation and the "State Action" Requirement: A Suggested New Approach, 48 IND. L.J. 304, 310-15 (1973). The alternative solution offered is "to place a heavy presumption of unconstitutionality on any racially identifiable school," and make it incumbent upon the board of education "to show that no discrimination on its part played a role in producing that racial duahism." Id. at 315 . This suggested approach is similar to that adopted by the Court in Denver. See notes 24 \& 25 infra and accompanying text. But the above formulation offered by Mr. Justice Douglas is hardly subject to criticism on the ground that evidentiary problems would render it difficult to apply, since his view of state action is so broad that problems of proof are significantly reduced. For another advocate of this view, see Fiss, Racial Imbalance in the Public Schools: The Constitutional Concepts, 78 HaRv. L. REv. 564, 584 (1965): "[I]n every case of racially imbalanced schools sufficient responsibility can be ascribed to governinent to satisfy the requirement that stems from the equal protection clause's proscription of unequal treatment by governinent." (Footnotes omitted.)

20. Cf. Swann v. Charlotte-Mecklenburg Bd. of Educ., 402 U.S. 1, $22-23$ (1971); 41 U. CIN. L. REv. 470, 480 (1972).

21. See 41 U. CrN. L. REv., supra note 20 , at 480.

22. 93 S. Ct. 2686 (1973).

23. Id. at 2697 (footnotes omitted).

24. Id. 
other unchallenged segregated schools within the system were not the product of a segregative intent. ${ }^{25}$ The Court did not find it necessary to rule that "a school district that has committed de jure segregation with respect to certain schools in a discrete area has a duty to desegreate [sic] all schools throughout the district."2B Rather, the Court took the position that a finding of intentional segregation in one part of a school district is "highly relevant" to the issue of the school board's intent regarding other segregated areas of the district. ${ }^{2 \pi}$

The newly resurrected "intent to segregate" inquiry ${ }^{28}$ may appar-

25. Id. at 2697-98.

26. Goodman, supra note 17 , at 276 n.6.

27. $93 \mathrm{~S}$. Ct. at 2697 . Mr. Justice Powell attempted to summarize the majority holding in Denver regarding the "new formulation" of what constituted a violation:

[D]esegregation will be ordered despite the absence of any segregatory laws if: (i) segregated schools in fact exist; (ii) a court finds that they result from some action taken with segregatory intent by the school board; (iii) such action relates to any "meaningful segment" of the school system; and (iv) the school board cannot prove that its intentions with respect to the remainder of the system were nonsegregatory. Id. at $2708 \mathrm{n} .15$ (Powell, J., concurring in part and dissenting in part) (emphasis added).

Mr. Justice Powell's interpretation apparently leaves little room for the imputation of segregative intent, a conclusion the Sixth Circuit so readily reached in Detroit. See notes 33-42 infra and accompanying text. It is clear that Mr. Justice Powell's use of the term "school board" generally refers to the "duly constituted public authorities" responsible for the particular segregative condition. Id. at 2705 .

28. The rebirth of the "intent to segregate" standard came over the strong protests of Mr. Justice Powell and Mr. Justice Douglas. Several arguments were raised to support the abandonment of the de jure-de facto distinction. First, Mr. Justice Powell pointed out that Denver was decided very shortly after Wright v. Council of City of Emporia, 407 U.S. 451 (1972), wherein the Court held motive irrelevant:

In addition, an inquiry into the "dominant" motivation of school authorities is as irrelevant as it is fruitless. The mandate of Brown II was to desegregate schools, and we have said that "[t]he measure of any desegregation plan is its effectiveness." Davis v. School Commissioners of Mobile County, 402 U.S. 33, 37. Thus, we have focused upon the effect-not the purpose or motivation - of a school board's action in determining whether it is a permissible method of dismantling a dual system. Id. at 462, cited in Keyes v. School Dist. No. 1 [Denver], 93 S. Ct. 2686, 2708-09 (1973).

See also Cisneris v. Corpus Christi Independent School Dist., 467 F.2d 142, 15051, 151 n.7 (5th Cir. 1972), cert. denied, 93 S. Ct. 3052 (1973). Mr. Justice Powell does accept the distinction that in Wright a prior constitutional violation had already been proved, while in Denver the Court was fundamentally concerned with the establishment of a violation. If this distinction is to be considered controlling, the result which prevails is unsatisfactory to Mr. Justice Powell, for "[t]he net result ... is the application of an effect test to the actions of southern school districts and an intent test to those in other sections, at least until an initial de jure finding for those districts can be made." Keyes v. School Dist. No. 1 [Denver], 93 S. Ct. 2686, 2709 (1973).

Second, Mr. Justice Powell argued that a de jure-de facto distinction based on motivation was inconsistent with the affirmative duty placed upon school authorities to eliminate segregation "root and branch," see Green v. County School Bd., 391 U.S. 430, 437-38 (1973); Swann v. Charlotte-Mecklenburg Bd. of Educ., 402 U.S. 1, 15 (1973), because that duty requires alleviation of conditions "which in large part 
ently be satisfied in several ways. As was observed in United States $v$. School Commissioners [Indianapolis]: ${ }^{29}$

[W]e can only emphasize that there are very few cases of school segregation today in which the defendants admit that they had an improper intent. Such intent may then be properly inferred from the objective actions. $^{30}$

Thus, the de jure "intent to segregate" may be imputed if two conditions are satisfied: (1) segregated schools do in fact exist within the area under consideration, and (2) the educational policy of the area under consideration falls within the authority of one decision-making body, such that the action or inaction of that body in promoting or maintaining segregative conditions reasonably implies an intent to perpetuate the segregative status quo. ${ }^{31}$ In Detroit, the Sixth Circuit con-

[do] not result from historic, state-imposed de jure segregation." 93 S. Ct. at 2704.

Third, a motivational inquiry would certainly run at cross-purposes with the enforcement of a student's constitutional right "to expect that once the State has assumed responsibility for education, local school boards will operate integrated school systems within their respective districts." Id. at 2706.

In addition to the constitutional arguments, Mr. Justice Powell offered policy reasons for abandonment of the de jure-de facto criterion. Since the requirement of segregative intent is an elusive one that will be difficult to apply and will give rise to unpredictable and inconsistent results, id. at 2709-10, a student's exercise of his constitutional rights will be unsatisfactorily contingent upon his particular geographical location, id. at 2708. See also Goodman, supra note 17, at 437. He also questioned the ability of a court to determine whether segregation exists in a "meaningful or significant" portion of a school district. $93 \mathrm{~S}$. Ct. at 2709 . In conclusion, Mr. Justice Powell stated: "Public schools are creatures of the State, and whether the segregation is state-created or state-assisted or merely state-perpetuated should be irrelevant to constitutional principle." Id. at 2707.

For a discussion of Mr. Justice Douglas' approach to the same problem, see note 19 supra.

29. 474 F.2d 81 (7th Cir. 1973).

30. Id. at 88 (emphasis added).

31. This is the fact situation which confronted the Sixth Circuit in Detroit. Some commentators have suggested that the intent requirement be dropped altogether in favor of a purely result-oriented approach. See generally Fiss, The Charlotte-Mecklenburg Case-Its Significance for Northern School Desegregation, 38 U. CHI. I. REV. 697 (1971). This approach focuses only on the segregated patterns themselves and is therefore more responsive to the school segregation problems in Northern cities. Id. at 706-07. See also Wright v. Council of City of Emporia, 407 U.S. 451, 462 (1972); Keyes v. School Dist. No. 1 [Denver], 93 S. Ct. 2686, 2709 (1973) (Powell, J., concurring in part and dissenting in part). This approach itself is subject to criticism under the theory that the mere fact that an injury is identified does not necessarily mean that the injured is entitled to relief. See note 9 supra. Kaplan, speaking about this objection to the result-oriented approach in the context of school districting on a geographical basis, starts from the proposition that

because the same harm is visited upon Negro children by districting on purely geographical lines as would be visited by racial segregation under force of law, the geographical districting must therefore be unconstitutional. In a sense, this is reasoning from the converse of the Brown and post-Brown 
fronted both conditions. ${ }^{32}$ But if inore than one decision-making body exercises authority in the area, more than one intention or purpose is necessarily involved, and thus a segregative singleness of purpose cannot be imputed to the collective body of decision-makers. Rather, a subjective analysis of each decision-maker's intention to coinply, to the extent of its authority, with the requirement of eliminating segregation is required of the court. Such was the analysis in effect undertaken by the Fourth Circuit in Richmond.

\section{Detroit_Imputing Segregative Intent}

The history of Detroit dates back to April 7, 1970, when the Detroit Board of Education adopted a desegregation plan designed to achieve better racial balance within the city schools of Detroit. ${ }^{33}$ Michigan's state legislature responded to this effort by enacting Act 48 of the Public Acts of $1970,{ }^{34}$ Section 12 of which delayed implementation of the plan. ${ }^{35}$ Subsequently the plaintiffs in this action, individual black and white children, their parents, and the NAACP, brought an action against the Board of Education of the City of Detroit and various state and local officials, challenging the constitutionality of Act 48 and seeking implementation of the desegregation plan. During the course of the ensuing hitigation, Act 48 was declared unconstitutional by the Court of Appeals for the Sixth Circuit, but the district court's subsequent denial of a motion for immediate implementation of the April 7 plan was upheld pending trial on the merits of plaintiffs' allegations that the Detroit schools were segregated. At trial, the district court held "that both the State of Michigan and the Detroit Board of Education have committed acts which have been causal factors in the segregated condition of the public schools of the City of Detroit." ${ }^{\text {"36 }}$ The court further observed that "[ $[\mathrm{t}] \mathrm{he}$ principal causes undemably have been population moveinent and housing patterns, but state and local governmental actions, including school board actions, have played a

cases. Kaplan, supra note 9, at 176.

But this criticism is not necessarily fatal to the result-oriented approach. If the view of Mr. Justice Douglas in his concurring opinion in Denver is adopted, then there is a constitutional violation whenever there is a segregated condition in public education. $93 \mathrm{~S}$. Ct. at 2701.

32. But cf. Petitioner's Brief for Certiorari at 19, Milliken v. Bradley, cert. granted, 42 U.S.L.W. 3300 (U.S. Nov. 20, 1973) (No. 73-434).

33. Bradley v. Milliken, 484 F.2d 215, 219 (6th Cir. 1973).

34. No. 48, \& 12, [1970] Mich. Pub. Acts 139, declared unconstitutional by the Court of Appeals for the Sixth Circuit in Bradley v. Milliken, 433 F.2d 897 (6th Cir. 1970).

35. 484 F.2d at 219.

36. 338 F. Supp. 582, 592 (E.D. Mich. 1971) (emphasis added). 
substantial role in promoting segregation."37 After further proceedings the lower court reached the conclusion that an adequately desegregated school system could not be established within the Detroit school district, and ordered preparation of a inetropolitan-wide plan to include cross district transportation of school children. The district court also tentatively defined the specific desegregation area to cover a fiftyfour school district area. The Sixth Circuit affirmed the trial court's finding of a violation-a determination that the unconstitutional segregative acts of the defendants, as officials or instrumentalities of the state, in validating and augmenting the effect of residential segregation, amounted to de jure segregation. ${ }^{38}$

Several factors undoubtedly influenced the court in its factual determination that the educational systein for the entire area was under the control of a single decision-making authority. Michigan's four constitutions make it clear that the Michigan public school system is solely a state function..$^{39}$ Furthermore, the school systems throughout the state are highly regulated by state laws, and "local school districts are instrumentalities of the State for administrative convenience."40 The extent to which Michigan exercises control over the local school districts is exemplified by the attempt of the legislature to repeal Detroit's desegregation plan by enactunent of Act $48 .{ }^{41}$ From this level of state control and involvement, the Sixth Circuit concluded that "the segregative actions and inactions of the Detroit Board of Education . . . are the actions of an agency of the State of Michigan." ${ }^{\prime 2}$

37. Id. (emphasis added).

38. 484 F.2d at 242.

39. See Mich. CONST. art. VII, $\S 2$ \& art. VIII, $\S ~ 1-3$ (1963); Mich. CoNST. art. XI, § 2 \& art. XI, § 9 (1908); MICH. ConsT. art. XIII, § 4 (1850); Mich. ConsT. art. X, $\$ 3$ (1835). See also Bradley v. Milliken, 484 F.2d 215, 245-46 (6th Cir. 1973).

40. 484 F.2d at 246 . The court noted the following as exemplary of state legislative control over public education:

... The Michigan School Code reaffirms the ultimate control of the State over public education. Local school districts must observe all State laws relating to schools, hold school a minimum number of days per year, employ only certified teachers, teach civics, health and physical education and drivers' education, excuse students to attend religious imstruction classes, observe State requirements when teaching sex education, make annual financial and other reports to the Superintendent of Public Instruction and must follow all rules and regulations of the State Department of Education. Id. at 248-49 (footnotes omitted).

In addition, the State Board of Education which is created by, and derives power from, the legislature, has the authority to merge districts and to withhold funds. IId. at 247-49. For the fifty-four school districts involved in the Detroit metropolitan plan, an average of 34 percent of the operating budgets is contributed by the state. $I d$. at 248 .

41. Id. at 249. The court did not find it necessary to point out the overt level of intent involved in the action of the legislature.

42. Id. at 238. The segregative actions and inactions which were accorded the 


\section{Richmond-Fragmented Decision-Making}

In Richmond, the Fourth Circuit was faced with a case of alleged segregation within certain school districts in a state with a prior history of statutorily imposed segregation. The district court had moreover concluded:

The City of Richmond's present pattern of residential housing contains well defined Black and White areas, which undoubtedly is a reflection of past racial discrimination contributed in part by local, state and federal government. ${ }^{43}$

Despite the willingness of the trial court in essence to impute an intent to segregate from past governmental actions, the Fourth Circuit held that "the last vestiges of state-imposed segregation have been wiped out in the public schools of the City of Richmond and the Counties of Henrico and Chesterfield. . . ." 44

In failing to uphold the district court's decision to impute the requisite intent, the court recognized a separate and distinct decision-making authority functioning in each of the political subdivisions comprising the metropolitan area. The Fourth Circuit based its conclusion as to the fragmented nature of decision-making authority in the Virginia public school systen on the following analysis: the court first cited case law authority supporting the proposition that the power to operate public schools in Virginia is, unlike in Michigan, ${ }^{45}$ "within the exclusive jurisdiction of the local school boards and not within the jurisdiction of the State Board of Education." 46 Furthermore, the court observed that, unlike in Michigan, under Virgimia constitutional and statutory law the State Board of Education acting alone lacked the power to effect consolidation of separate scliool districts into a single

rank of state action and which were therefore found to be constitutional violations were (1) segregative zoning and assignment practices, id. at 221 ; (2) the use of "optional areas," (where pupils in an area were provided with a choice of attending either of two designated schools), id. at 232; and (3) building construction and site selection, id. at 235 .

43. 338 F. Supp. at 72. The segregative acts found by the district court included violations in the selection of school construction sites, id. at 86-87; the drawing of attendance zones to conform to segregatory residential patterns, id. at 82-83; and a past practice of transporting students across district lines to maintain segregation, $i d$. at 83. As in Detroit, the constitutional violations were imputed to the state defendants, who were also found to have committed specific violations. Note, supra note 7 , at 1685.

44. 462 F.2d at 1070.

45. See notes $39-42$ supra and accompanying text.

46. Bradley v. School Bd., 462 F.2d 1058, 1067 (4th Cir. 1972), aff'd by an equally divided Court, 93 S. Ct. 1952 (1973), citing County School Bd. v. Griffin, 204 Va. 650, 133 S.E.2d 565 (1963). 
system under the control of a single school board, and that local school boards were fiscally dependent upon the local governing bodies. ${ }^{47}$

Having established that the decision-making authority is held primarily at the local level, the Fourth Circuit reasoned that the intent to segregate cannot be imputed from segregatory conditions throughout the metropolitan area. Rather, the imquiry must be directed toward the subjective intent demonstrated by the various decision-making units. The court clearly conducted this factual inquiry: ${ }^{48}$

[N]either the record nor the opinion of the district court even suggests that there was ever joint interaction between any two of the units involved (or by higher state officers) for the purpose of keeping one unit relatively white by confining blacks to another. ${ }^{40}$

Thus, the Fourth Circuit not only failed to impute an intent to segregate from segregatory conditions but also failed to find any subjective motivation on the part of the metropolitan authorities to perpetuate racial imbalance..$^{50}$

The Sixth Circuit in Detroit expressly atteinpted to reconcile its approach to the metropolitan segregation problem with that of the Richmond case on two grounds: (1) Richmond involved an order to consolidate immediately three separate school districts while Detroit merely involved a direction to study plans for the reassignment of pupils

47. $462 \mathrm{~F} .2 \mathrm{~d}$ at 1067-68.

48. A case relied upon by the majority in Richmond, 462 F.2d at 1070, and by the dissenters in Detroit, 484 F.2d at 261-62, 277, is Spencer v. Kugler, 326 F. Supp. 1235 (D.N.J. 1971), aff'd mem., 404 U.S. 1027 (1972). Spencer was a class action on behalf of black scliool clildren in New Jersey alleging that racial imbalance in the public sclools of that state resulting from the drawing of sclool district lines coincident with municipal boundaries amounted to a denial of equal protection. In liolding that the imbalance anounted to a situation of irremedial de facto segregation, the court stated:

The setting of municipalities as local school districts is a reasonable standard especially in light of the municipal taxing authority. The system as provided by the various legislative enactments is unitary in nature and intent and any purported racial imbalance within a local school district results from an imbalance in the population of that municipality-school district. Racially balanced municipalities are beyond the pale of either judicial or legislative intervention. Id. at 1240 (empliasis added).

Actually Spencer contributes little to the problem of reconciling Richmond and Detroit because, while involving only one decision-making authority to which de jure intent might be imputed, "there was no allegation that state action caused or contributed to the racial inbalance." Bradley v. School Bd. [Richmond], 462 F.2d 1058, 1079 (4th Cir. 1972) (Winger, J., dissenting). The distinction between Spencer and the facts of Richmond proposed by the dissent in Richmond, also offers little to this discussion, that distinction being that Virginia had a history of state-imposed segregation wlile New Jersey did not. Id. If that distinction were controlling both Detroit and Richmond should have been decided differently.

49. Bradley v. School Bd., 462 F.2d 1058, 1065 (4th Cir. 1972) (emphasis added).

50. Cf. Note, supra note 7, at 1684 . 
in the inetropolitan Detroit area; ${ }^{51}$ and (2) the jurisdiction of localities over schools in Virginia is exclusive, while in Michigan there is considerable state involvement in local school affairs. ${ }^{52}$ The first distinction is unconvincing as it exalts form over substance. However, the second distmction, while understandably failing to link explicitly the state involvement mquiry to the "intent to segregate test," nevertheless conforms to the approach offered as a basis for reconciliation by this Note. ${ }^{53}$

\section{Cross-District Assignment as a Remedy for De JuRE Segregation}

Upon the establishment of a metropolitan intent to segregate, the question arises as to the type of remedy the courts are einpowered to apply. In this vein, the cross-district assignment of school children has been termed a disruptive and ill-conceived "legal inonstrosity." 54

51. 484 F.2d at 251.

52. Id.

53. Any attempt to reconcile Richmond and Detroit within the context of the basic constitutional doctrine as now prescribed by Denver may be coinplicated by the fact that neither the Fourth nor the Sixth Circuit anticipated the forthconning Denver intent test. (Richmond was decided on June 5, 1972, and affirmed by an equally divided Supreme Court without opinion on May 21, 1973; Detroit was decided by the Sixth Circuit en banc on June 12, 1973; and Denver was handed down by the Supreine Court on June 21, 1973). Furthermore, both cases involved multidistrict probleins while Denver was concerned with but a single school district. Neither ground for distinction affects the validity of the analytical framework developed in this Note, although the latter does complicate the practicality of applying the Denver standard because the requisite intent to segregate must be subjectively established over a multidistrict area where more than one decision-making authority may be involved. A court faced with this more difficult inquiry might find it desirable to ease the plaintiff's burden by adopting another suggestion from Denver. In Denver the Court held that a showing of intentional segregative policy on the part of school authorities in a "meaningful segment" of a school district not only constituted a prima facie case that a violation existed within that portion of the district, but also shifted the burden of proof to the school authorities to show "that their actions as to other segregated schools within the system were not also motivated by segregative intent." $93 \mathrm{~S}$. Ct. at 2697-98. The Court explained under what circumstances this burdenshifting principle can be employed: "There are no hard and fast standards governing the allocation of the burden of proof in every situation. The issue, rather, 'is merely a question of policy and fairness based on experience in the different situations." " Id. at 2698, quoting $9 \mathrm{~J}$. WigMORE, EVIDENCE $\$ 2486$ (3d ed. 1940). In the multidistrict situation a court might accept a showing of intentional segregative school policy within a "meaningful segment" (e.g., a single school district) of a metropolitan area as a prima facie case of a constitutional violation for the entire inetropolitan area and shift the burden to the various decision-making authorities involved to show otherwise.

54. Bradley v. Milliken, 484 F.2d 215, 260 (6th Cir. 1973) (dissenting opinion). 
Brown II, ${ }^{55}$ which set forth the basic doctrine to govern the implementation of the mandate of Brown I, characterized the principles of equity to be applied in fashioning remedies as follows: "Traditionally, equity has been characterized by a practical flexibility in shaping its remedies and by a facility for adjusting and reconciling public and private needs." ${ }^{\text {"56 }}$ In Swann v. Charlotte-Mecklenburg Board of Education, ${ }^{67}$ which presents a coinplete statement of judicial desegregation remedies, the Court held that a district court has broad equitable powers to remedy problems of scgregation once a constitutional right and a violation thereof have been established. ${ }^{58}$ Although "the list [of remedies] is open-ended in the civil rights cases, and is limited only by scope of the practical considerations of enforcement," decree in any equity case must also be judged by its effectiveness, ${ }^{00}$ must be limited in scope by the nature of the violation, ${ }^{61}$ and must be confined to the achievement of its objective, which im desegregation cases is held to be the dismantling of a dual school system. ${ }^{22}$

Detroit held that it is within the equity power of a district court to require a metropolitan area desegregation plan which involves crossdistrict assignment of school children. The court's rationale was predicated on the initial determination that there was sufficient evidence in the record to support the district court's finding that a constitutionally adequate desegregation plan could not be developed within the Detroit school system alone. ${ }^{03}$ Thus, with the identification of a constitutional

55. Brown v. Board of Educ., 349 U.S. 294 (1955) (Brown II).

56. Id. at 300, citing Hecht Co. v. Bowles, 321 U.S. 321, 329-30 (1944); Alexander v. Hillman, 296 U.S. 222, 239 (1935). See also Lemon v. Kurtzman, 93 S. Ct. 1463, 1469 (1973); Board of Educ. v. Dowell, 375 F.2d 158, 165 (10th Cir.), cert. denied, 387 U.S. 931 (1967); Armstrong v. Board of Educ., 323 F.2d 333, 340 (5th Cir. 1963); H. McClintock, HaNdBoOK of The PRINCIPLES of EQUity $\$ 30$ (2d ed. 1948); Note, supra note 7 , at 1690 .

57. 402 U.S. 1 (1971).

58. Id. at 15 .

59. D. DOBBS, HANDBOOK ON THE LAW OF REMEDIES $\S 7.4$, at 534 (1973).

60. See Green v. County School Bd., 391 U.S. 430 (1968).

61. Swann v. Charlotte-Mecklenburg Bd. of Educ., 402 U.S. 1, 16 (1971).

62. Id. at 28. Recognizing that the scope of the remedial powers is not unlimited, Chief Justice Burger did not offer any "fixed guidehnes," but did note that the remedial authority did not put judges in the shoes of school officials. Id. at 27; Note, supra note 7, at 1690. Cf. Wright v. Council of the City of Emporia, 407 U.S. 451, 477 (1972) (Burger, J., dissenting): "[T]he invocation of remedial jurisdiction is not equivalent to having a school district placed in receivership."

63. Bradley v. Milliken, 484 F.2d 215, 245 (6th Cir. 1973). Consider the language of the court:

This court never before has been confronted by a finding that any less comprehensive a solution than a metropolitan area plan would result in an all black school system immediately surrounded by practically all white suburban school systems, with an overwhelmingly white majority population in the total metropolitan area. 
right and a violation of that right, the court affirmed the power of a district court to remedy the violation. ${ }^{64}$ In defining the extent of that power, the Sixth Circuit theorized that the mandate of Brown I would be nullified if the school district boundaries surrounding the city were held to be inviolable even after a de jure intent to segregate had been attributed to the metropolitan authorities. ${ }^{65}$ The net result would, of course, be the restoration of the doctrine of separate but equal schools. ${ }^{66}$ Relying heavily upon $S w a n n,{ }^{67}$ the court in Detroit concluded that artificial school district boundary lines are not absolute: "If school boundary lines cannot be changed for an unconstitutional purpose, it follows logically that existing boundary lines cannot be frozen for an unconstitutional purpose." In Richmond, it is difficult to identify with precision exactly how the power of a district court to reinedy a violation is regarded by the Fourth Circuit since that court was unable to discern a constitutional violation in the establishment or maintenance of the three school districts. ${ }^{69}$

\section{CONCLUSION}

The thesis of this Note has been that Richmond and Detroit are, in theory at least, reconcilable within the de jure-de facto framework as recently constructed in Denver. ${ }^{70}$ Judicial inquiry is not foreclosed

64. While agreeing with the district court's conclusion that it can fashion a metropolitan-wide desegregation plan, the court of appeals expressed no opinion as to the specific desegregation area defined by the lower court. Id. at 252. The court also vacated the district court's order dated July 11, 1972, to purchase 295 school buses as premature. The use of this device as a remedy was not ruled out, however, pending approval of a final desegregation plan. Id.

65. See 484 F.2d at 249.

66. $I d$.

67. Id. at $255-58$.

68. Id. at 250 .

69. 462 F.2d at 1069 . The court does recognize the power to consolidate where there is a determination of invidious discrimination in the establishment or maintenance of local governmental units. Id. at 1060.

70. The question remains, of course, whether the basis for reconciliation offered here presents the courts with a suitable basis for deciding cases in the future. On the strength of Denver, this Note has accepted the de jure-de facto distinction as an apparently continuing factor to be reckoned with. It is recognized that this basic test itself is subject to considerable criticisin. See Goodman, supra note 17, at 435 . Not only is the distinction subject to the same criticisms as were leveled at it by Mr. Justice Douglas and Mr. Justice Powell in Denver, but it is also particularly suspect in the metropolitan situation where more than one decision-n1aking authority is involved, because the motivation of several school districts regarding their actions or inactions concerning the school policies of each other will be even more difficult to establish and will lead to even more unpredictable and inconsistent results. Furthermore, there is a tendency anong judges to regard a remedy such as the metropoli- 
by platitudes extolling or denigrating the sanctity of school district boundaries. Rather, the focus on illegal de jure purpose or intent is defined by the scope of the authority of the decision-making organ whose actions or mactions are being questioned in light of segregative conditions. Where segregated patterns in fact exist within a metropolitan area, and where there is one decision-making autlority responsible for school policy in that area, it is logically possible from the objective circumstances to impute the requisite intent in order to find de jure desegregation. But where local decision-making authorities control school policy from autonomous political subdivisions comprising a metropolitan area, there must be a subjective showing of a collective effort purposely to bring about or maintain segregative conditions. ${ }^{71}$ Once a violation is estabhshed, there appears to be little dis-

tan solution as punishment rather than remedy. Cf. Bradley v. Milliken, 484 F.2d 215, 260 (6th Cir. 1973) (dissenting opinion): "[T]he adjoining three counties and the fifty-two school districts [should not] be penalized because they are located near Detroit" (enuphasis added). If there has been a showing that racial imbalance in an urban area has resulted from segregative actions of state or local officials in promoting or perpetuating that imbalance, and if a solution cannot be effected within the boundaries of that city, the involvement of outlying areas should not be regarded by the judiciary as suburban punishment. Nor should such a solution be prohibited on the ground that the local authorities did not purposely contribute to the maintenance of segregative conditions in the urban area, because the metropolitan solution is a remedy for the existing violation and the scope of the remedy must be great enough to erase the violation.

71. It is recognized that the test proposed by this Note is necessarily difficult to apply because a variety of factors must be considered in order to identify the governmental decision-naaking entity for a particular area. It might therefore be of some value to speculate as to the probable outcome of the application of the test in one or two other jurisdictions.

In New York, for example, the Commissioner of Education has "exceedingly wide powers in any matter relating to the vast educational systen of the State," Benm v. Wilson, 279 App. Div. 277, 110 N.Y.S.2d 94 (1952), and has exclusive jurisdiction "in all matters relating to the supervision and control of the public school system, the discipline of the schools and the management of the school property and the authority and discretionary acts on the part of officers or agencies of education," Bomar v. Cole, 177 Misc. 740, 32 N.Y.S.2d 825 (S. Ct. 1941). The Commissioner is chosen by, and serves at the pleasure of, the Board of Regents, N.Y. Educ. LAw $\$ \$ 302-03$ (McKinney 1969), and vacancies on the Board of Regents are filled by the New York Legislature, id. $\$ 202$. The Board of Regents is, therefore, an agency of the state and the Commissioner is a servant of that agency. The Commissioner's broad powers over local school matters include: (1) the power to "annul upon cause shown to his satisfaction any certificate of qualification granted to a teacher by any authority whatever," $i d$. $\S 305(7)$; (2) the power to remove, subsequent to a hearing, any trustee, member of a board of education, superintendent of scliools, or other school officer for any wilful violation of a duty imposed by state law or for wilfully disobeying any order, rule or regulation of the regents or the Commissioner, id. $\$ 306(1)$; (3) the power to withhold public money from any school district for its wilfully disobeying any provision of law or any decision, order, or regulation of the regents or the Commissioner, id. $\$ 306(2)$; 
pute that the scope of the remedy is limited only by the scope of the violation.

and (4) the power to "reorganize" local school districts, id. \$ 314. While the Commissioner does not have the power to consolidate districts without the consent of the local board of education, id. $\$ 1524$, he may order a change in school district boundaries by means of reorganization without the board's consent under $\$ 314$. Board of Trustees v. Commissioner of Educ., 37 App. Div. 2d 743, 322 N.Y.S.2d 924 (1971). Regarding the specific area of school desegregation, the Board of Regents has declared racially imbalanced schools to be educationally inadequate. Vetere v. Allen, 15 N.Y.2d 259, 258 N.Y.S.2d 77, 206 N.E.2d 174, cert. denied, 382 U.S. 825 (1965). Where the Commissioner has taken action to implement this policy by directing a school board to reorganize attendance zones, his determination is conclusive, "absent a showing of pure arbitrariness." Id. See also Radford v. Gage, 59 Misc. 2d 948, 301 N.Y.S.2d 282 (S. Ct. 1969). Considering this extensive power over local school policy that is vested in an agency of the state of New York, it is not unlikely that a court, faced with a set of facts similar to those presented in Detroit and Richmond, would conclude that a single governmental decision-making authority is involved.

In Illinois, the outcome of the application of the test is not quite so clear. The legislature has delegated to the local pohtical subdivisions the power to create new school districts or to change school district boundaries by detachment, annexation, division, dissolution, or consolidation. IIL. ANN. STAT. ch. 122, \$\$ 7-1 to -2 (Simith-Hurd 1962). But it is clear that this delegation of power is permissive and uot exclusive. It is merely a matter of legislative policy to leave to the resident voters the settlement of questions involving school district boundaries. People ex rel. Smail v. Board of Educ., 343 IIl. App. 362, 99 N.E.2d 385 (1951). Accordingly, the local subdivisions are considered to be acting as "agents of the legislature." Board of Educ. v. Board of Educ., 11 I1l. App. 2d 408, 415, 137 N.E.2d 721, 725 (1956). See also People ex rel. Community Unit School Dist. No. 1 v. Decatur School Dist. No. 61, 45 III. App. 2d 33, 194 N.E.2d 659 (1964). The legislature has retained complete power over the school district boundaries: "The area comprising a school district may be divided, contracted or abolished at the will of the legislature." Board of Educ. v. Board of Educ., 11 III. App. 2d 408, 415, 137 N.E.2d 721, 725 (1956). See also Community Unit School Dist. No. 6 v. County Bd., 9 Ill. App. 2d 116, 132 N.E.2d 584 (1956). In the specific area of discrimination in schools, the legislature has retained control over policy by providing that upon the filing of a complaint signed by 50 residents of a district or by ten percent of the residents of a district, whichever is lesser, the Superintendent of Public Instruction (an elected state official) shall direct that there be a hearing upon the allegations. If the Superintendent of Public Instruction determines that a violation exists, he shall request the Attorney General to apply to the appropriate court to rectify the practice. IrL. ANN. STAT. ch. 122, \$ 22-19 (Smith-Hurd 1962). In addition, the Illinois Legislature has provided that for cities of over 500,000 inhabitants the city will constitute one school district under the charge of one board of education. Id. $\$ 34-2$. Among the powers granted to this board is the power to subdivide the district into attendance zones, but with the direction that "no pupil shall be excluded from or segregated im any such school on account of his color, race, sex or nationality." Id. $\$ 34-18$. Furthermore, the legislature has provided that the board has an affirmative duty to make periodic revision of attendance zones in order to prevent segregation. Id., as amended, (Supp. 1973). While much of the power over local school pohicy in Illinois has been delegated to the local political subdivisions, it is clear that these local authorities act as agents of the state and with the permission of the legislature. Furthermore, the state has retained direct control over pohicy involving school desegregation matters. Thus, it appears likely that a court would identify a single governmental decision-making entity for a multidistrict problem arising in Illinois. 